\title{
Relation between sediment-water fluxes of oxygen and silicate and faunal abundance at continental shelf, slope and deep-water stations in the northwest Mediterranean
}

\author{
T. M. Tahey, G. C. A. Duineveld, E. M. Berghuis, W. Helder \\ Netherlands Institute for Sea Research, PO Box 59, 1790 AB Den Burg, Texel, The Netherlands
}

\begin{abstract}
Measurements of sediment oxygen demand (SOD), silicate fluxes, benthic macro- and meiofauna and phytopigments were made on continental shelf, slope and deep-water sediments in the northwest Mediterranean in November-December 1991. The mean SOD ( \pm SD), measured by onboard incubations of sediment cores with overlying water, was $301 \pm 83 \mu \mathrm{mol} \mathrm{m}^{-2} \mathrm{~h}^{-1}$ for the shelf stations, $146 \pm 53 \mu \mathrm{mol} \mathrm{m}^{-2} \mathrm{~h}^{-1}$ for the slope stations, and $44 \pm 10 \mu \mathrm{mol} \mathrm{m} \mathrm{m}^{-2} \mathrm{~h}^{-1}$ for the deep-water stations. The SOD values for the slope and deep-water stations are comparable to earlier reported data from open oceanic sites. Considering the limited data set that we present, substantial downslope transport of organic matter at these stations cannot be concluded. Mean silicate effluxes from the sediment, measured in the same incubation experiments, amounted to $52 \pm 14,48 \pm 20$ and $16 \mu \mathrm{mol} \mathrm{m}^{-2} \mathrm{~h}^{-1}$ for shelf, slope and deep-water stations, respectively. Diffusive oxygen and silicate fluxes were calculated from pore-water profiles with Fick's first law of diffusion. The irrigation flux was defined as the difference between incubation and diffusive flux. The oxygen irrigation flux contributed on average $39 \pm$ $10 \%, 17 \pm 15 \%$ and $5 \pm 5 \%$ to the oxygen incubation flux for the shelf, slope and deep-water stations, respectively, and showed a strong positive relation with macrofaunal density, illustrating the importance of macrofaunal activities on sediment-water solute exchanges. In contrast to the oxygen irrigation fluxes, the silicate irrigation fluxes showed less distinction between shelf and slope stations and contributed on average $60 \pm 6 \%, 61 \pm 9 \%$ and $19 \%$ to the silicate incubation fluxes for the shelf, slope and deep-water stations, respectively. The relation between silicate irrigation flux and macrofaunal density was not significant. Another indication for the lack of organic matter transport across the slope was the monotonic decrease of faunal density, biomass and phytopigments with increasing depth. Only at the upper slope station were traces of a past deposition event found. Below this depth phytopigments were below detection level. The absence of phaeopigments in the near-bottom water and their high concentration in the shelf sediments indicated little resuspension of sediment.
\end{abstract}

KEY WORDS: Mediterranean - Sediment oxygen demand - Silicate fluxes - Infauna - Phytopigments

\section{INTRODUCTION}

The bottom of the Gulf of Lions in the NW Mediterranean is characterized by a relatively narrow and shallow continental shelf, connected to the abyssal depths by a steep slope. The slope is intersected by numerous submarine canyons (Got et al. 1985). Despite a widely open south side, the Gulf is rather isolated due to the prevailing hydrographic conditions. The continuous SW surface flow over the slope (Liguro-
Provincal current) entrains the less saline coastal water, admixed with Rhone input, on the shelf (Millot 1987). The water masses in the deep offshore area and in coastal areas are separated by a frontal zone, with a wedge of saline water next to it consisting of upwelled Levantine Intermediate Water (Minas \& Minas 1989). According to Cruzado \& Velasquez (1989), import of open sea water is mainly confined to the eastern half of the Gulf, whereas a mixture of open sea water and fresh water is exported at the southwest end of the 
Gulf. An alternative way for particulate matter from the shelf to reach the offshore area is by means of water cascading down the slope, as has been observed in cold winters (Minas \& Minas 1989). Aloïsi et al. (1982) and Monaco et al. (1987) reported that particulate organic matter can be transported from the shelf to the slope and the deep sea via a nepheloid bottom layer which is directed offshore by submarine canyons.

During a cruise in November-December 1991 in the Gulf of Lions as part of the EROS 2000 (European River Output System) project, sediment oxygen demand (SOD) was measured at 8 sampling sites in the shelf, upper slope and deep-water areas by means of shipboard incubation of intact sediment cores. In combination with these measurements, the abundance and standing stock of macro- and meiofauna in the incubation cores were analysed, as well as the phytopigment content of the sediment and of the surface and bottom water. All these parameters give information on the availability and, therefore, also on the possible redistribution of organic particles which have sunk from the euphotic production zone.

Since oxygen respiration is the principal mineralization process in the sediments of the Gulf of Lions (Helder 1989b), SOD measurements yield a minimum estimate for carbon flux to the sediment. Oxygen uptake by the microbial community is governed by diffusion of $\mathrm{O}_{2}$ This process can be adequately described by modelling pore-water profiles of $\mathrm{O}_{2}$ (Revsbech et al. 1980, Rasmussen \& Jørgensen 1992). Larger fauna, on the other hand, usually have some means to actively ventilate burrows and tubes, giving rise to an irrigation flux. This activity may also enhance the respiration of the microbial community (Aller 1980, Emerson et al. 1985, Aller \& Aller 1992, van Duyl et al. 1992). Irrigation fluxes along the transect were calculated by subtracting diffusive fluxes of $\mathrm{O}_{2}$ and silicate from their (total) incubation fluxes (Kanneworff \& Christensen 1986, Archer \& Devol 1992, Rasmussen \& Jørgensen 1992). Combining these measurements with data on the standing stock of meioand macrofauna provides insight into the specific activity of the community. Furthermore, because of their relatively long life-span, macro- and meiofauna standing stock can be considered an integrated measure for benthic food input (Schaff et al, 1992). In addition, earlier flux measurements for oxygen in the area of interest in combination with the present ones could shed some light on the seasonal variation of benthic respiration and could provide an estimate for the annual carbon input to the sediment.

Finally, phytopigments in the sediment can, because of their differential stability (Abele-Oeschger 1991), provide insight into recent as well as past deposition events, whereas phytopigment fingerprints of the bottom water can reveal different sources of phytodetritus input.

\section{MATERIALS AND METHODS}

Site description. Fig. 1 shows the location of the 8 stations visited during the cruise with the RV 'Tyro' in the Gulf of Lions in November-December 1991. Four of them are situated on the shallow shelf (Stns $12 \& 23$ ) and the adjacent upper slope (Stns $14 \& 20$ ) of the Gulf of Lions. Two stations (Stns $3 \& 19$ ) are located in the deep-water region, and another two on the shallow shelf near the mouth of the Ebro (Stns 29 \& 30). Locations, dates of sampling and water depth at the stations are summarized in Table 1.

Box coring. Box cores were taken with a modified Reineck box corer (cylindrical corer of $50 \mathrm{~cm}$ diameter), which was equipped with a hydraulically dampened closing lid containing a valve to compensate for pressure effects during retrieval. Visual inspection of the core usually revealed clear overlying water and the presence of microstructures at the sediment surface. Any disturbed cores were rejected. In order to check whether leakage of the overlying water of the box core had occurred during retrieval, silicate concentrations in the overlying water of the box core were compared with those of the deepest CTD bottle $(5 \mathrm{~m}$ above the sea floor) at each station (see 'Water column' section). Because silicate concentrations in the water column were always increasing with water depth (Helder et al. unpubl.), and silicate concentrations in the overlying box core water were always higher than those of the deepest CTD bottle, displacement or mixing of the original overlying box core water with water of more shallow origin could be excluded.

Sediment grain size, carbon, nitrogen. At every station, small sediment cores $(2.5 \mathrm{~cm}$ diameter $)$ of the upper $10 \mathrm{~cm}$ of the sediment were taken from the box cores. The core samples were immediately deepfrozen on board for later analysis. In the laboratory, the upper $5 \mathrm{~cm}$ slices of these samples were defrosted, diluted and sieved $(63 \mu \mathrm{m})$. The fraction $<63 \mu \mathrm{m}$ was caught on a pre-weighed filter. All sediment fractions were dried at $60^{\circ} \mathrm{C}$. The silt content $(<63 \mu \mathrm{m})$ was calculated as percentage of total dry weight. The residual fractions $(>63 \mu \mathrm{m})$ were too small in volume to subdivide into more categories. The percentages of organic carbon and organic nitrogen in the sediment were determined with a Carlo Erba NA $1500 \mathrm{CN}$ analyser, after sample acidification according to Verardo et al. (1990).

Water column. At all stations, a depth profile of temperature and salinity of the water column was made with a CTD mounted on a rosette sampler. Simultaneously, water samples were taken at specific depths with Niskin bottles for the analysis of nutrients, oxygen (Winkler method) and phytopigments. Water samples for pigment analysis (ca 20 l) were filtered (Whatman GF/F filters, $0.7 \mu \mathrm{m}$ ) and subsequently deep-frozen. 
Fig. 1 The study area in the northwest Mediterranean. Numbers refer to sampling stations. Depth contours (m) are indicated

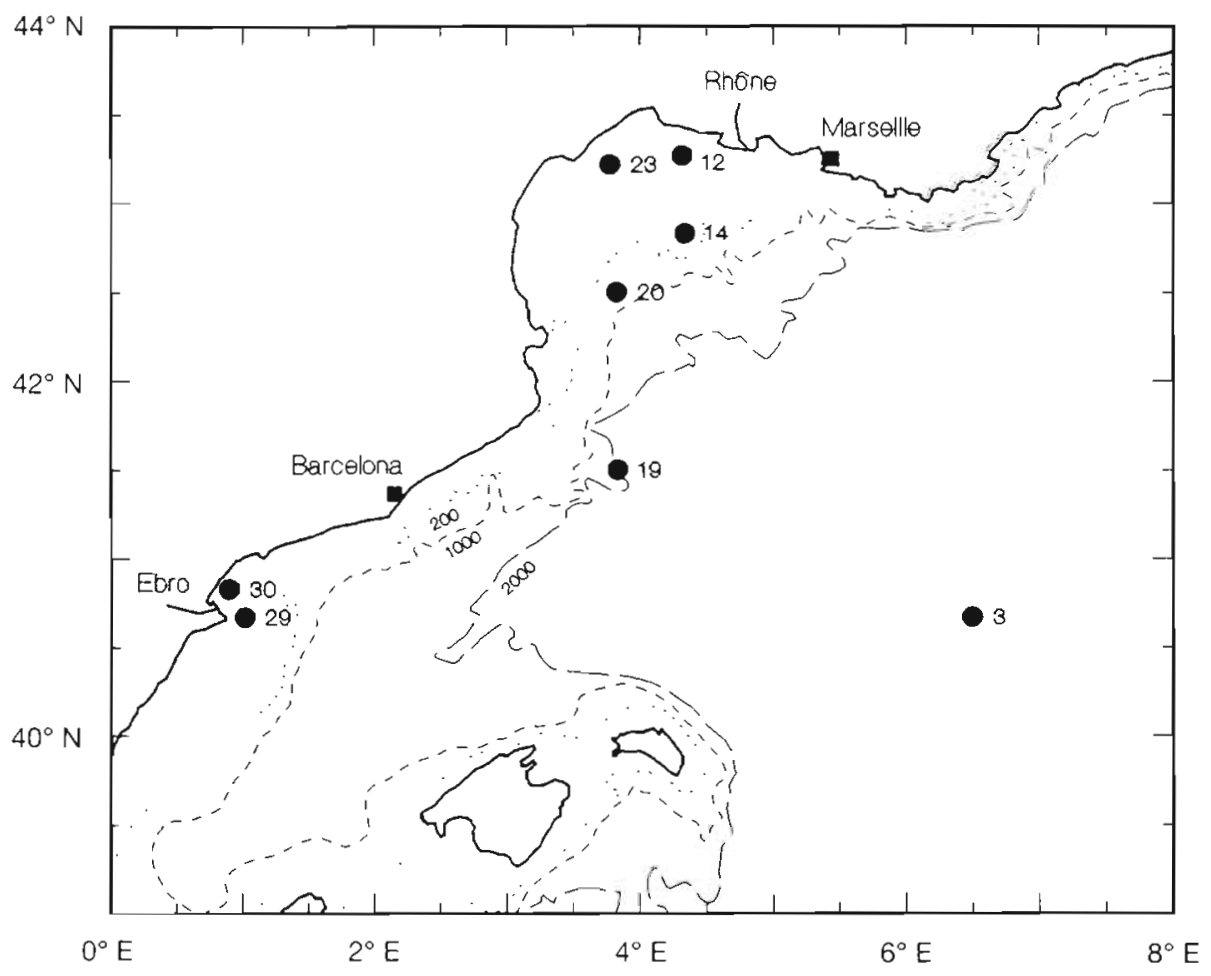

Pore-water profiles. Oxygen profiles were made in subcores on deck at in situ temperature with an oxygen microelectrode (Diamond electrode type 737, with an electrode-tip diameter of $50 \mu \mathrm{mi}$, attached to a micromanipulator, at every $0.5 \mathrm{~mm}$ depth interval. Porewater profiles of dissolved silicate were made with a depth resolution of $0.5 \mathrm{~cm}$ in surface sediments ( 0 to $2 \mathrm{~cm}$ ) and at 1 to $2 \mathrm{~cm}$ intervals deeper down in the cores. Procedures for oxygen and silicate profiles were according to Helder (1989a). Detailed results of pore-water profiling will be reported elsewhere (Helder et al. unpubl.).

Diffusive fluxes. Pore-water profiles of $\mathrm{O}_{2}$ and silicate were used to calculate diffusive fluxes, assuming molecular diffusion (Berner 1980) and applying Fick's first law:

$$
J=-\Phi \cdot D_{\mathrm{s}} \cdot(\mathrm{d} C / \mathrm{d} x)_{x=0}
$$

where $\Phi=$ porosity; $D_{s}=$ the whole-sediment molecular diffusion coefficient; and $(\mathrm{d} C / \mathrm{d} x)_{x=0}=$ the concentra tion gradient across the sediment-water interface, with $x$ positive downward. In the case of $\mathrm{O}_{2}, \mathrm{dC} / \mathrm{d} x$ was determined as the largest difference in $\mathrm{O}_{2}$ concentration at the point where the microelectrode penetrated the sediment. In the case of silicate the pore-water concentrations in the upper $2 \mathrm{~cm}(n=5)$ were fitted by a second order polynomial, and $\mathrm{d} C / \mathrm{d} x$ was derived from the formula. Silicate was chosen as a tracer because it is not significantly involved in redox reactions and, because of the magnitude of the concentration gradient across the sediment-water interface, usually shows significant fluxes (Helder \& Andersen 1987). A porosity of 0.85 at the sediment-water interface was used, on the basis of earlier studies (Helder 1989b). The molecular diffusion coefficient, $D_{0}$, was adjusted to the in situ temperature using the Stokes-Einstein relation (Li \& Gregory 1974). $D_{0}$ values for silicate and oxygen were derived from Wollast \& Garrels (1971) and Broecker \& Peng (1974), respectively. The wholesediment molecular diffusion coefficient $\left(D_{\mathrm{s}}\right)$ was then calculated according to Ullman \& Aller (1982):

$$
D_{\mathrm{s}}=D_{0} \cdot \Phi^{2}
$$

Incubation fluxes. On deck, a perspex chamber (31 cm diameter) was gently inserted into the box core, which still had the in situ bottom water on top. The chamber was sealed with a lid containing a YSI 620 electrode and stirrer and subsequently placed in a thermostatically controlled incubator at in situ temperature.

$\mathrm{O}_{2}$ flux was derived by continuously recording the $\mathrm{O}_{2}$ concentration in the overlying water during the time of incubation, which was, depending on location, between 3 and $24 \mathrm{~h}$. At the end of the incubation period, 3 samples were taken from the overlying water for Winkler titration in order to calibrate the readings of the electrode. $\mathrm{O}_{2}$ flux, expressed as $\mu \mathrm{mol} \mathrm{m} \mathrm{m}^{-2} \mathrm{~h}^{-1}$, was determined by means of a linear regression on the initial decrease in $\mathrm{O}_{2}$ concentration in the chamber time series (Hall et al. 1989). 
Silicate concentrations in the incubation cores were measured by taking $10 \mathrm{ml}$ water samples with a syringe from overlying water at regular time intervals ( 1 to $2 \mathrm{~h}$ ) during the incubation. The fluxes were determined by linear regression on the concentration-time series. The removal of the sample volume was compensated by adding a similar volume of bottom water to the incubation core by a second syringe. The samples were sieved through $0.45 \mu \mathrm{m}$ Nuclepore filters and silicate was analysed on a Technicon-TRAACS 800 auto-analyser, following with minor modifications the methods described in Strickland \& Parsons (1972).

Fauna. The sediments of the incubation chamber were washed over a $0.5 \mathrm{~mm}$ sieve at the end of the incubation for analysis of macrofauna. The residue on the sieve was preserved in a buffered solution of formalin ( $4 \%$ in seawater). Organisms were identified to higher taxonomic levels (Family, Order). Biomass was estimated from the shell-free wet weight (blotted), and converted into ash-free dry weight (AFDW) with the appropriate conversion factors given by Rumohr et al. (1987). The faunal similarity of the stations was determined by means of cluster analysis with the BrayCurtis index as a measure of dissimilarity (Bloom 1981).

Meiofauna was collected from the sediment section outside the incubation chamber with a corer of $1.5 \mathrm{~cm}$ diameter and $10 \mathrm{~cm}$ length. Five such cores were pooled into one sample. In the laboratory the samples were coloured with rose bengal/phenol (Thiel 1966). The meiofauna in these samples was retrieved by means of elutriation and sieving over a $50 \mu \mathrm{m}$ screen (Uhlig et al. 1973) and subsequently counted. Fauna smaller than the meiofauna, i.e. protozoa and bacteria, were not quantified.

Pigment analysis. Pigments in surface and bottom waters as well as in the top sediment layer $(0$ to $1 \mathrm{~cm})$ were analysed by means of reverse phase HPLC, using a Waters Associate liquid chromatograph equipped with a RoSil C18 column and a Model 991 Waters photodiode array spectrophotometer. Prior to extrac- tion, sediment (ca $3 \mathrm{~g}$ dry wt) and filters were freezedried and homogenized. Pigments were extracted in $5 \mathrm{ml}$ methanol with $2 \%$ ammonium acetate. The solvent and gradient system was similar to that described by Kraay et al. (1992). The flow rate was set at $0.80 \mathrm{ml} \mathrm{min}^{-1}$. Pigments were identified by comparing their absorbance spectra with those of reference standards obtained from algal cultures. Calibration curves were made after isolating a pigment and diluting it in a specific solvent to a series of different concentrations. The appropriate solvents and the corresponding extinction coefficients were derived from the literature (Bidigare 1991). The dilution series were injected in the system and the resulting peak areas were recorded. Concentrations were quantified from the maximum absorption with the Lambert-Beer law.

\section{RESULTS}

\section{Sediment and water column characteristics}

All stations had uniformly high percentages of silt (Table 1). The percentages of organic carbon and organic nitrogen are shown in Fig. $2 \mathrm{a}$ and $\mathrm{b}$ respectively. It appears that there is a decrease in percentage organic carbon with depth in the sediment. Little variation in organic carbon content between the stations was detected. The nitrogen content of the sediment displayed no obvious relation with depth in the sediment. C/N ratios (Fig. 2c) varied little with depth in the sediment as well as between stations (range 4 to 9), except for the top layer of $\operatorname{Stn} 3$ (C/N ratio of 17 ), which was due to the high percentage organic carbon in this layer. The low $\mathrm{C} / \mathrm{N}$ ratios, with mean values of $\mathrm{ca} 8$, are an indication of relatively fresh organic detritus (Jørgensen 1983).

The vertical temperature differences in the water column were small at all stations, i.e. temperatures ranged between 13 and $17^{\circ} \mathrm{C}$. At the deep-water

Table 1. Sampling stations in the Gulf of Lions, NW Mediterranean, showing location, sampling date, water depth and percentage silt $(<63 \mu \mathrm{m})$. The last 4 columns show characteristics of the bottom water, viz. temperature, salinity, oxygen concentration and oxygen saturation. Stations are ranked according to depth

\begin{tabular}{|c|c|c|c|c|c|c|c|c|c|}
\hline \multirow[t]{2}{*}{ Stn } & \multicolumn{2}{|c|}{ Location } & \multirow{2}{*}{$\begin{array}{c}\text { Date } \\
\text { (1991) }\end{array}$} & \multirow{2}{*}{$\begin{array}{l}\text { Depth } \\
(\mathrm{m})\end{array}$} & \multirow{2}{*}{$\begin{array}{l}\text { Silt } \\
(\%)\end{array}$} & \multirow{2}{*}{$\begin{array}{l}\text { Temp. } \\
\left({ }^{\circ} \mathrm{C}\right)\end{array}$} & \multirow{2}{*}{$\begin{array}{l}\text { Sal. } \\
(\%)\}\end{array}$} & \multirow{2}{*}{$\begin{array}{c}\mathrm{O}_{2} \text { conc } \\
(\mu \mathrm{M})\end{array}$} & \multirow{2}{*}{$\begin{array}{c}\mathrm{O}_{2} \text { sat } \\
(\%)\end{array}$} \\
\hline & ${ }^{\circ} \mathrm{N}$ & ${ }^{\circ} \mathrm{E}$ & & & & & & & \\
\hline 12 & 43.16 & 4.19 & $25 \mathrm{Nov}$ & 60 & 98.3 & 13.7 & 38.216 & 214 & 84 \\
\hline 23 & 43.13 & 3.47 & $01 \mathrm{Dec}$ & 80 & 97.7 & 14.0 & 38.172 & 207 & 81 \\
\hline 29 & 40.40 & 1.01 & $04 \mathrm{Dec}$ & 60 & 98.2 & 15.0 & 38.151 & 243 & 98 \\
\hline 30 & 40.50 & 0.54 & $04 \mathrm{Dec}$ & 60 & 96.9 & 15.3 & 37.932 & 249 & 100 \\
\hline 14 & 42.50 & 4.20 & 26 Nov & 480 & 90.9 & 13.4 & 38.540 & 195 & 76 \\
\hline 20 & 42.30 & 3.50 & 29 Nov & 680 & 95.8 & 13.3 & 38.520 & 193 & 75 \\
\hline 19 & 41.30 & 3.50 & 29 Nov & 2300 & 93.7 & 13.1 & 38.447 & 209 & 81 \\
\hline 3 & 40.40 & 6.30 & 21 Nov & 2725 & 92.5 & 13.2 & 38.446 & 211 & 82 \\
\hline
\end{tabular}



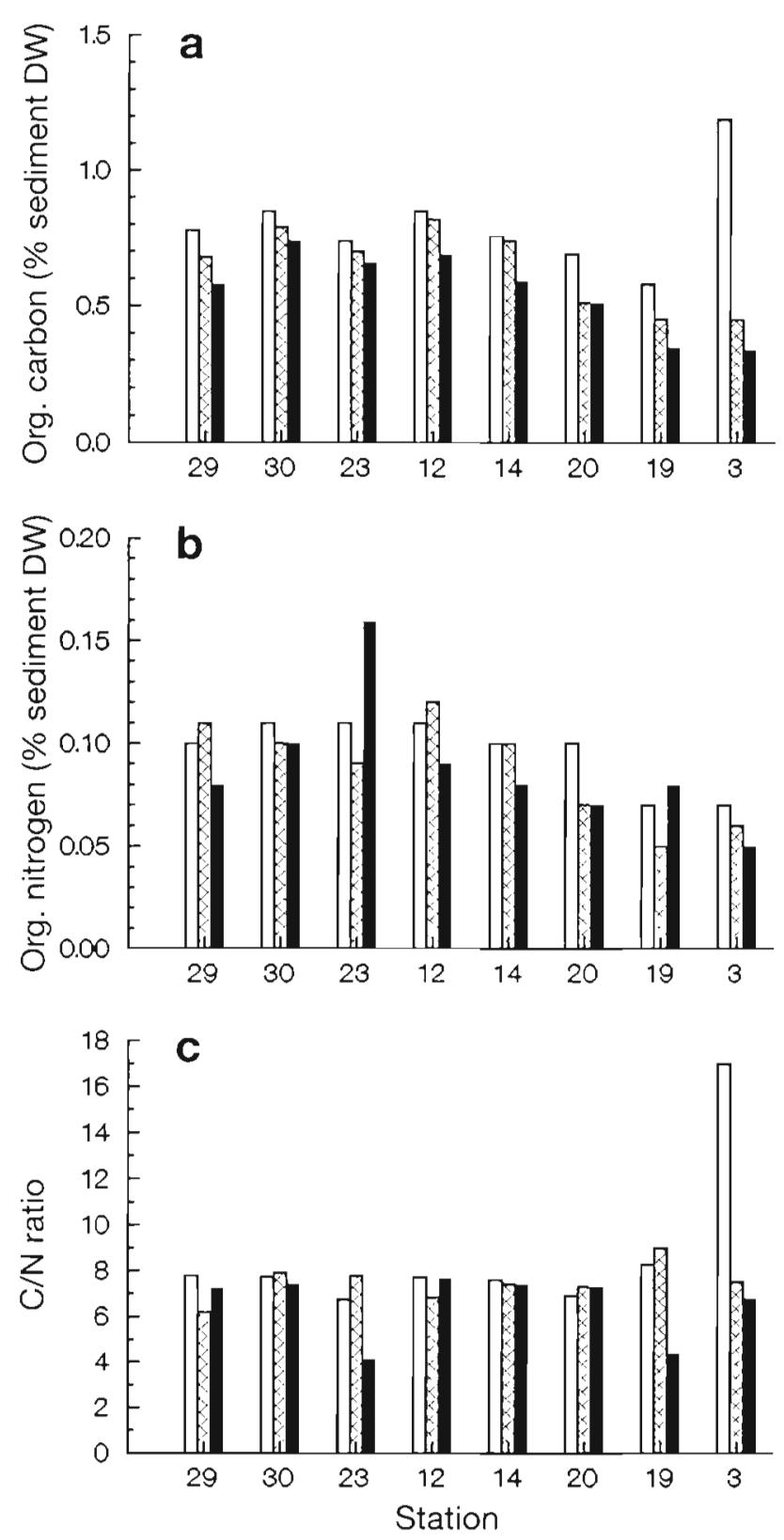

Fig. 2. (a) Organic carbon content, and (b) organic nitrogen content, of the sediment ( $\%$ sediment dry wt) for 3 sediment depth layers at the 8 stations. (c) $\mathrm{C} / \mathrm{N}$ ratio for the 3 sediment depth layers. Depths in the sediment are: 0 to $5 \mathrm{~mm}$ (Stn 23: 0 to $10 \mathrm{~mm}$ ), 100 to $140 \mathrm{~mm}$ (Stn 23: 140 to $180 \mathrm{~mm}$; Stn 30: 80 to $100 \mathrm{~mm}$ ). Stations are ranked according to water depth

Stns $3 \& 19$ and the slope Stns 14 \& 20, the thermocline was situated at a depth of 50 to $70 \mathrm{~m}$. Stns $29 \& 30$ near the Ebro had a homogeneous, well-mixed water column. Table 1 gives the temperature, salinity, oxygen concentration and oxygen saturation of the bottom water. The temperature of the bottom water ranged between 13.1 and $15.3^{\circ} \mathrm{C}$ at the stations, whereas the oxygen concentration of the bottom water varied between 193 and $249 \mu \mathrm{mol} \mathrm{l}^{-1}$. A distinction can be noticed in Table 1 between the bottom water over the slope (Stns 14 \& 20) and the deep water (Stns 3 \& 19) with respect to all parameters measured $\left(\mathrm{O}_{2}\right.$, salinity, temperature).

\section{Flux measurements}

\section{Oxygen}

The similarity of in situ conditions in overlying bottom water (temperature, $\mathrm{O}_{2}$ concentration; Table 1) among stations facilitated direct comparison of oxygen fluxes (for effects of variation in overlying water $\mathrm{O}_{2}$ concentration on fluxes see Rasmussen \& Jørgensen 1992). Fluxes in the incubation chambers ranged from 190 to $412 \mu \mathrm{mol}$ $\mathrm{m}^{-2} \mathrm{~h}^{-1}$ (mean $\pm \mathrm{SD}: 301 \pm 83$ ) at the shelf stations $(<100 \mathrm{~m})$, from 85 to $182 \mu \mathrm{mol} \mathrm{m}^{-2} \mathrm{~h}^{-1}(146 \pm 53)$ at the slope stations ( 100 to $1000 \mathrm{~m}$ ), and from 37 to $55 \mu \mathrm{mol}$ $\mathrm{m}^{-2} \mathrm{~h}^{-1}(44 \pm 10)$ at the 2 deep stations (Table 2). Estimates from duplicate incubations were very close, with the largest discrepancy at Stn 12. The range of incubation fluxes at the shallow stations was rather large, due mainly to the relatively low rates at Stn 23.

Examples of contrasting pore-water oxygen profiles, representative for relatively high (Stn 12) and low (Stn 3) organic carbon input to the sediment, are given in Fig. 3. The range of diffusive oxygen fluxes was 190 to $248 \mu \mathrm{mol} \mathrm{m}^{-2} \mathrm{~h}^{-1}$ (mean $\pm \mathrm{SD}: 192 \pm 62$ ) at the shelf stations, 89 to $130 \mu \mathrm{mol} \mathrm{m}^{-2} \mathrm{~h}^{-1}(110 \pm 29)$ at the slope stations, and 35 to $95 \mu \mathrm{mol} \mathrm{m}^{-2} \mathrm{~h}^{-1}(65 \pm 42)$ at the deep stations (Table 2).

Fig. 4 shows the decrease in SOD with water depth. In contrast to the slope and deep stations, the diffusive fluxes at the shallow stations appear to be significantly

Table 2. Oxygen fluxes $\left(\mu \mathrm{mol} \mathrm{m}^{-2} \mathrm{~h}^{-1}\right)$ measured in incubations and calculated from pore-water profiles, and the resulting irrigation fluxes. Irrigation fluxes marked with an asterisk are given as zero, because the negative difference between incubation and diffusive flux is theoretically meaningless (see text). Values separated by a slash are the results of duplicate box cores. Stations are ranked according to depth

\begin{tabular}{|rrrrr|}
\hline Stn & Depth $(\mathrm{m})$ & Incubation & Diffusive & Irrigation \\
\hline 12 & 60 & $412 / 318$ & 248 & $164 / 70$ \\
23 & 80 & $190 / 215$ & 105 & $85 / 110$ \\
29 & 60 & 338 & 194 & 144 \\
30 & 60 & 334 & 219 & 115 \\
14 & 480 & $170 / 182$ & 130 & $40 / 52$ \\
20 & 680 & 85 & 89 & $0^{\circ}$ \\
19 & 2300 & 55 & 95 & $0^{*}$ \\
3 & 2725 & $37 / 39$ & 35 & $2 / 4$ \\
\hline
\end{tabular}



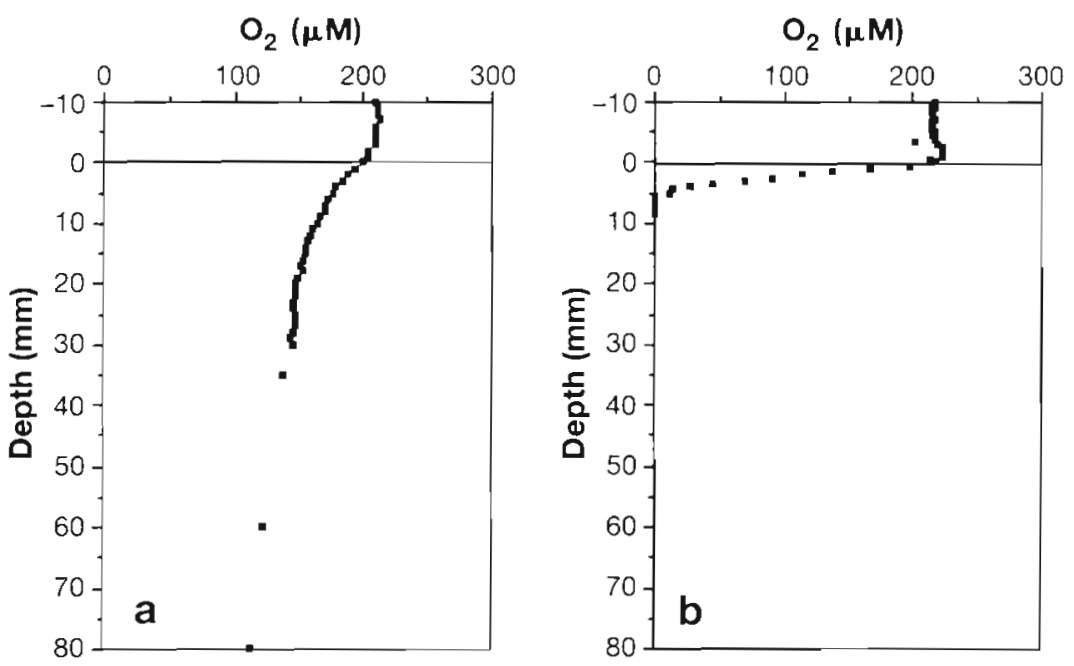

Fig. 3. Examples of constrasting pore-water $\mathrm{O}_{2}$ profiles. (a) $\mathrm{O}_{2}$ is present $(>100 \mu \mathrm{M})$ over the entire depth range of the profile ( $\operatorname{Stn} 3$ ). (b) $\mathrm{O}_{2}$ concentration reaches zero at $5 \mathrm{~mm}$ depth in the sediment ( $\operatorname{Stn} 12$ )

lower than the incubation fluxes. It can furthermore be noticed that the 2 deep stations have slightly different values for incubation as well as for diffusive $\mathrm{O}_{2}$ fluxes.

The irrigation flux (incubation minus diffusive flux) ranged from 70 to $164 \mu \mathrm{mol} \mathrm{m} \mathrm{m}^{-2} \mathrm{~h}^{-1}$ at the shelf stations, from 0 to $52 \mu \mathrm{mol} \mathrm{m}^{-2} \mathrm{~h}^{-1}$ at the slope stations, and from 0 to $4 \mu \mathrm{mol} \mathrm{m} \mathrm{m}^{-2} \mathrm{~h}^{-1}$ at the deep stations (Table 2). In cases where the calculated irrigation flux was negative, which is theoretically impossible and attributable to variability and measurement error, it was considered to be 0 . Fig. 5 shows the positive relation between macrofauna density and the oxygen irrigation flux $(\mathrm{r}=0.95, \mathrm{n}=12, \mathrm{p}<0.01)$.

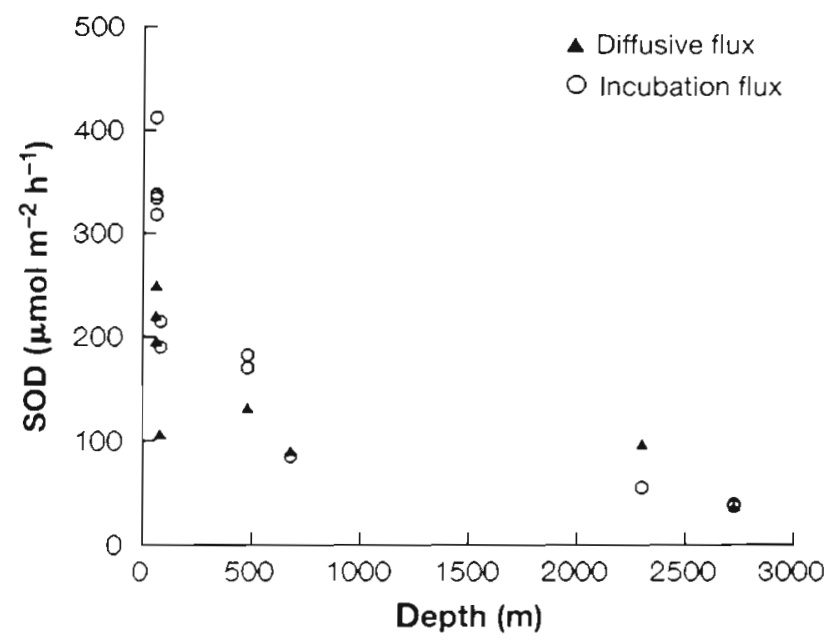

Fig. 4. SOD (sediment oxygen demand) at various water depths measured on board in November-December 1991 (Table 2). Incubation and diffusive fluxes are given. The $\mathrm{O}_{2}$ fluxes are directed into the sediment
Oxygen incubation fluxes can be used to calculate carbon demand for the sediment, using a respiratory coefficient of 0.85 (Hargrave 1973). The resulting benthic carbon demand varies between 47 and $101 \mathrm{mg} \mathrm{C} \mathrm{m} \mathrm{m}^{-2} \mathrm{~d}^{-1}$ for the shelf stations, 21 to $45 \mathrm{mg} \mathrm{C} \mathrm{m}^{-2} \mathrm{~d}^{-1}$ for the upper slope stations, and 9 to $14 \mathrm{mg} \mathrm{C} \mathrm{m}{ }^{-2} \mathrm{~d}^{-1}$ for the deep stations.

\section{Silicate}

The diffusive as well as incubation fluxes of silicate showed a less distinct difference between shelf, slope and abyssal stations. Incubation flux ranged from 31 to $66 \mu \mathrm{mol} \mathrm{m}{ }^{-2} \mathrm{~h}^{-1}$ (mean $\pm \mathrm{SD}$ : $52 \pm 14$ ) at the shallow stations, from 29 to $66 \mu \mathrm{mol} \mathrm{m} \mathrm{m}^{-2} \mathrm{~h}^{-1}(48 \pm 20)$ at the slope stations, and was $16 \mu \mathrm{mol} \mathrm{m}^{-2} \mathrm{~h}^{-1}$ at the deep Stn 19 (no measurement made at Stn 3; Table 3). Diffusive silicate fluxes ranged from 11 to $26 \mu \mathrm{mol} \mathrm{m}{ }^{-2} \mathrm{~h}^{-1}$ (mean $\pm \mathrm{SD}$ : $18 \pm 8$; no measurement at Stn 30 ) at the shelf stations, from 13 to $20 \mu \mathrm{mol} \mathrm{m}{ }^{-2} \mathrm{~h}^{-1}$ $(17 \pm 5)$ at the slope stations, and from 2 to $13 \mu \mathrm{mol}$ $\mathrm{m}^{-2} \mathrm{~h}^{-1}(8 \pm 8)$ at the deep stations. The diffusive flux at shelf $\operatorname{Stn} 23$ was close to the low diffusive flux of the deep Stn 19. Slope Stn 14 exhibited a slightly elevated diffusive silicate flux, comparable to the shelf stations (except Stn 23). In Fig. 6 both the incubation and the diffusive silicate fluxes are plotted against water depth. Diffusive fluxes were always lower than the corresponding incubation fluxes. However, in contrast

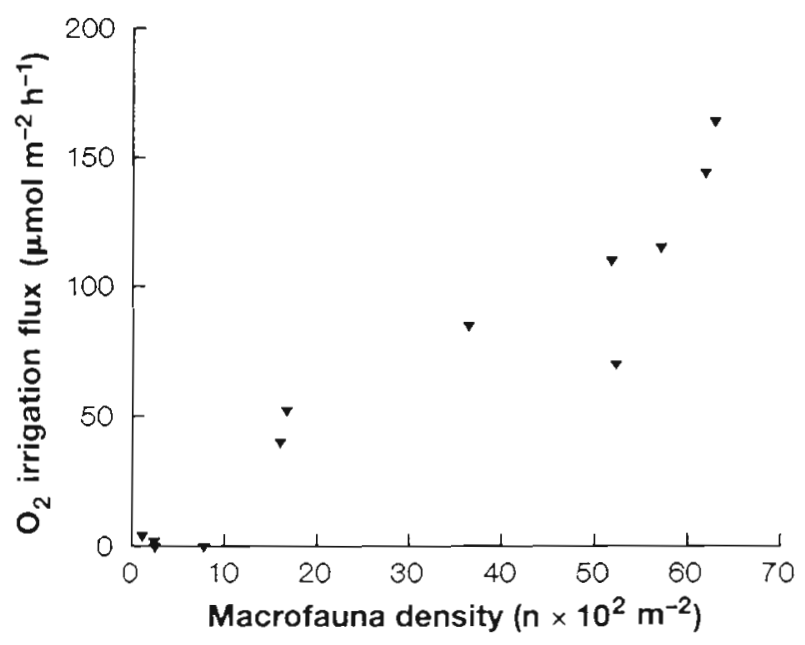

Fig. 5. $\mathrm{O}_{2}$ irrigation fluxes at the stations, with the corresponding macrofaunal densities (Tables $2 \& 4$ ). The correlation between both variables has a coefficient of $r=0.95$ $(\mathrm{n}=12, \mathrm{p}<0.01)$ 
Table 3. Silicate effluxes from the sediment ( $\mu \mathrm{mol} \mathrm{m}^{-2} \mathrm{~h}^{-1}$ ) measured in incubations and calculated from pore-water profiles, and the resulting irrigation fluxes. Values separated by a slash are the results of duplicate box cores. Stations are ranked according to depth

\begin{tabular}{|rrrrr|}
\hline Stn & Depth (m) & Incubation & Diffusive & lrrigation \\
\hline 12 & 60 & $53 / 66$ & 26 & $27 / 40$ \\
23 & 80 & 31 & 11 & 20 \\
29 & 60 & 49 & 18 & 31 \\
30 & 60 & 62 & - & - \\
14 & 480 & $48 / 68$ & 20 & $28 / 48$ \\
20 & 680 & 28 & 13 & 15 \\
19 & 2300 & 16 & 13 & 3 \\
3 & 2725 & - & 2 & - \\
\hline
\end{tabular}

to the oxygen fluxes (Fig. 4), the differences between incubation and diffusive silicate fluxes at the slope stations were rather large.

Irrigation flux of silicate ranged from 20 to $40 \mu \mathrm{mol}$ $\mathrm{m}^{-2} \mathrm{~h}^{-1}$ at the shallow stations and from 15 to $48 \mu \mathrm{mol}$ $\mathrm{m}^{-2} \mathrm{~h}^{-1}$ at the slope stations, and was $3 \mu \mathrm{mol} \mathrm{m} \mathrm{m}^{-2} \mathrm{~h}^{-1}$ at the deep Stn 19. In Fig. 7 the silicate irrigation flux is plotted against macrofauna density. The relation with macrofauna density is less obvious than in the case of the $\mathrm{O}_{2}$ irrigation fluxes $(\mathrm{r}=0.42, \mathrm{n}=8, \mathrm{p}>0.05)$.

\section{Benthic fauna}

Table 4 shows the biomass and density of total macrofauna and the density of the meiofauna. Densities of both groups decreased with increasing water depth. Stn 23 had a significantly lower meiofaunal density than

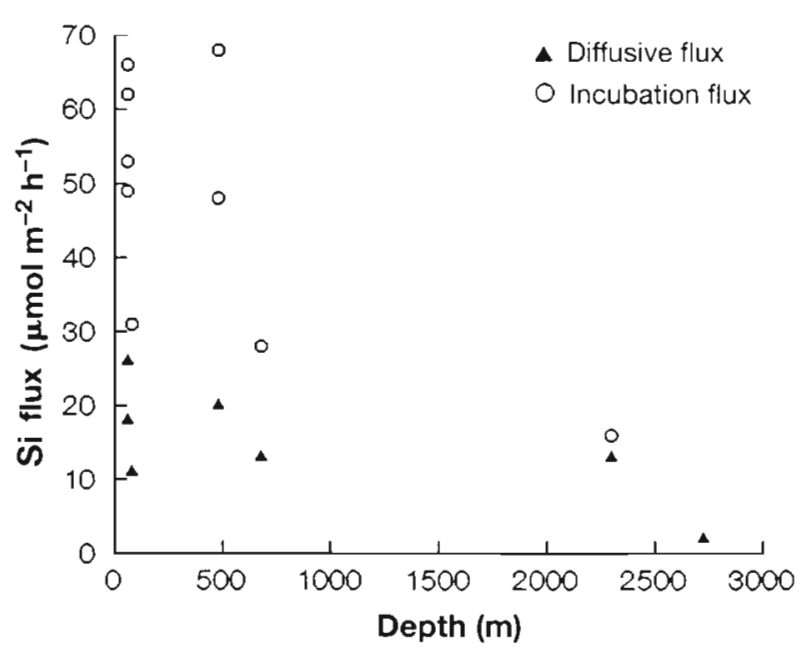

Fig. 6. Incubation and diffusive silicate fluxes at various water depths measured on board in November-December 1991 (Table 3). The Si fluxes are directed out of the sediment the other slope stations. In contrast to the macrofauna, meiofaunal density differed clearly between the 2 deepwater Stns 3 and 19 (Table 4). Despite the low meiofaunal density at $\operatorname{Stn} 23$, the relation between macroand meiofaunal density is clear $(\mathrm{r}=0.85, \mathrm{n}=12$, $\mathrm{p}<0.01$ ). Although both macro- and meiofauna are capable of enhancing solute transport, macrofauna is generally the most important group in this respect (Aller $\&$ Aller 1992). For this reason we used only macrofaunal density in comparisons with the irrigation fluxes of silicate and oxygen. Macrofaunal biomass was more variable than the density because of the incidental occurrence of large specimens. At the shallow stations biomass ranged from 940 to $3350 \mathrm{mg} \mathrm{AFDW} \mathrm{m}^{-2}$, at the shallowest station on the slope (Stn 14) biomass was still $1750 \mathrm{mg}$ on average, but deeper on the slope (Stn 20) and in the abyssal plain (Stns $19 \& 3$ ) macrofaunal biomass decreased by 1 and 2 orders of magnitude, respectively. Both macrofaunal biomass and densities of our 2 deep stations compare well to those of a study at NE Atlantic deep-sea sites (4000 to $5000 \mathrm{~m}$ ) by Rutgers van der Loeff \& Lavaleye (1986).

The taxonomic composition of the macrofauna at the shallow stations showed a high degree of similarity, especially at Stn 12 in the Gulf of Lions and at the 2 stations near the Ebro (Stns 29 \& 30; Table 5). Dominant taxa at these stations were small polychaetes (spionids, cirratulids and paraonids), the bivalve genus Thyasira and small crustaceans (amphipods, cumaceans). The other shallow station in the Gulf of Lions (Stn 23) had lower numbers of polychaetes and bivalves but a higher density of isopods. The macrofauna on the continental slope (Stns 14 \& 20) still comprised a fair number of taxa, but densities

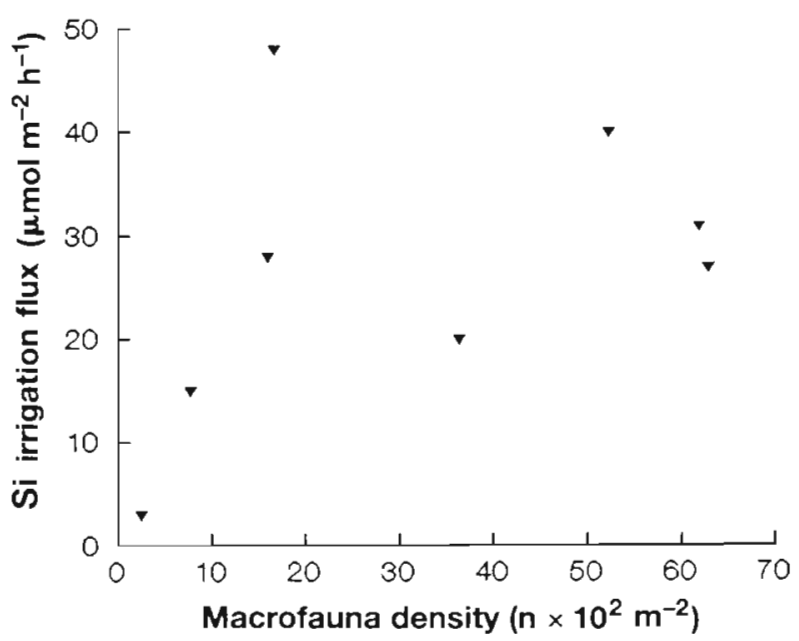

Fig. 7. Si irrigation fluxes at the stations, with the corresponding macrofaunal densities (Tables $3 \& 4$ ). The correlation between both variables has a coefficient of $r=0.42$ $(\mathrm{n}=8, \mathrm{p}>0.05)$ 
Table 4. Macrofaunal biomass ( $\mathrm{mg}$ AFDW $\mathrm{m}^{-2}$ ) and density (ind. $\times 10^{2} \mathrm{~m}^{-2}$ ) and meiofaunal density (ind. $\times 10^{6} \mathrm{~m}^{-2}$ ) at the stations. Values separated by a slash are the results of duplicate box cores. Stations are ranked according to depth

\begin{tabular}{|rrrrc|}
\hline Stn & Depth & \multicolumn{2}{c}{ Macrofauna } & Meiofauna \\
& $(\mathrm{m})$ & Biomass & Density & density \\
\hline 12 & 60 & $2010 / 2140$ & $62.9 / 52.3$ & 1.83 \\
23 & 80 & $940 / 1290$ & $36.4 / 51.8$ & 0.38 \\
29 & 60 & 1060 & 61.9 & 1.64 \\
30 & 60 & 3350 & 57.1 & 1.92 \\
14 & 480 & $1510 / 1990$ & $16.0 / 16.7$ & 0.55 \\
20 & 680 & 270 & 7.8 & 0.42 \\
19 & 2300 & 29 & 2.5 & 0.34 \\
3 & 2725 & $14 / 10$ & $2.4 / 1.1$ & 0.07 \\
\hline
\end{tabular}

were considerably lower, notably those of the dominant shelf polychaetes. Only 1 taxon, viz. sipunculids, occurred on the slope but not on the shelf, albeit in very low densities. The macrofauna at the deep stations was quite impoverished in terms of both number of taxa and density.

Table 5. Density (ind. $\mathrm{m}^{-2}$ ) of selected dominant taxa at the stations. Stations are ranked according to their faunal similarity by means of cluster analysis with the Bray-Curtis index as a measure for dissimilarity

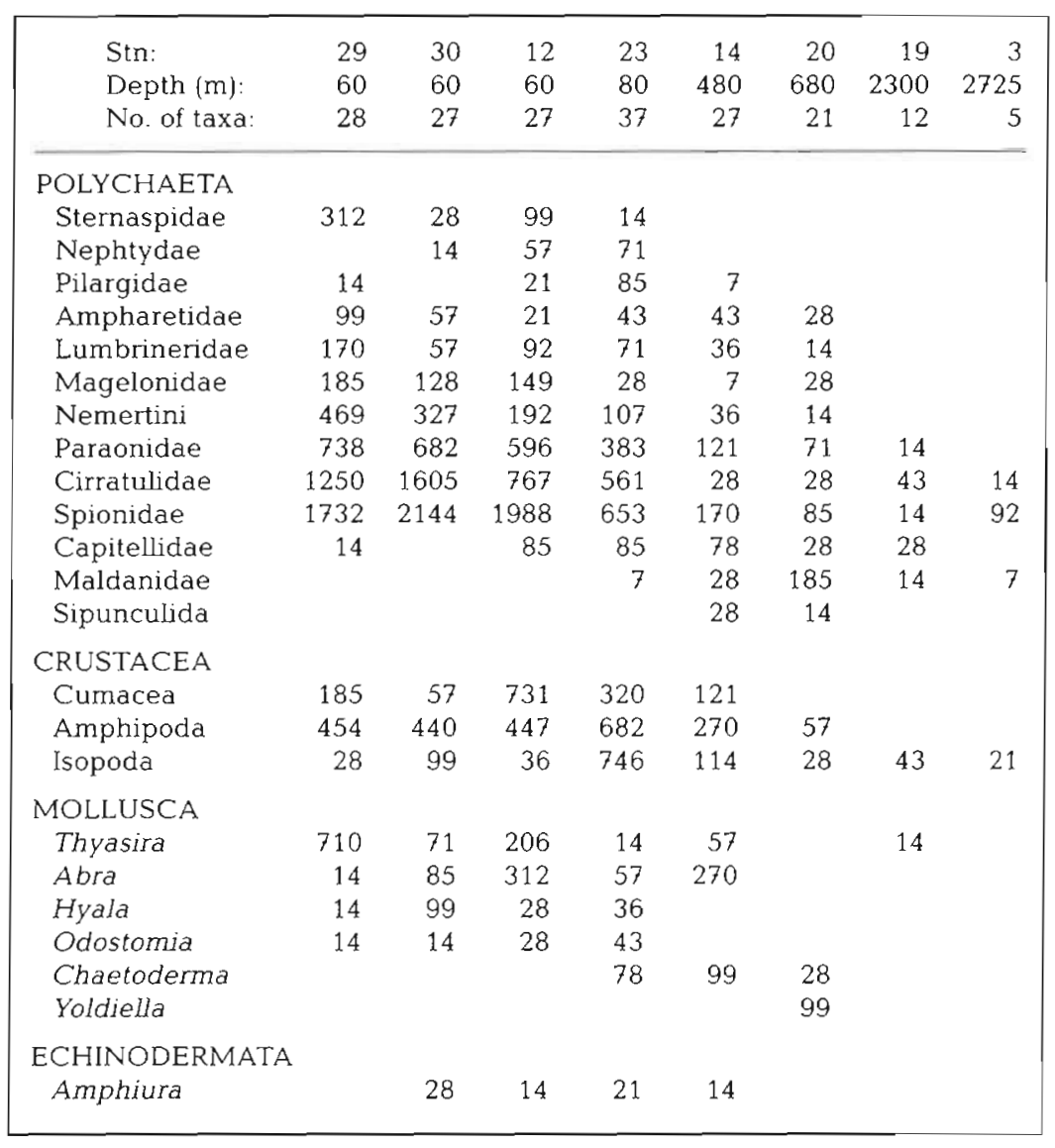

\section{Phytopigments}

Table 6 summarizes the concentrations of the principal pigments found in the bottom water and sediments with HPLC analysis. Samples of the upper sediment layer from the deep stations did not yield any detectable amounts of phytopigments. The same was true for the deepest slope Stn 20. Samples from the more shallow slope Stn 14, however, contained a relatively modest amount of a chl a derivative, phaephorbides and fucoxanthin (+ fucoxanthin-like) pigments. A similarly modest amount of chl a was found at the shelf Stn 12 , but with a higher fucoxanthin-like component. The sediment at the remaining 3 shelf stations contained much higher levels of chl $a$ and accessory pigments and also displayed a greater number of unidentified peaks. When considering only the fresh pigments (marked with asterisks in Table 6), sediments from the Ebro stations yielded the highest concentrations, although the relative amounts of the different pigments differed greatly at both stations. The chl a content at Stn 30 was almost twice that found at the adjacent Stn 29, whereas the sediment at the latter station contained twice as much fucoxanthin.

The bottom water over the slope and deep stations was fairly similar in phytopigment composition (Table 6), with minimal amounts of fresh chl a and fucoxanthin. The bottom water over the shelf had, in general, much higher concentrations of chl $a$ and accessory pigments, especially fucoxanthin (+fucoxanthin-like) compounds. None of the bottom water samples contained quantifiable traces of phaeopigments (phaeophorbides, phaeophytin). The bottom water over the Ebro Stns $29 \& 30$ was different from that over the Gulf of Lions in that it contained chl $c$, which was not found elsewhere. With respect to the labile pigment chl $a$, there was reasonable agreement between concentrations in the bottom water and in the corresponding sediment. The most striking difference between bottom water and sediment pigment concentrations was found at the slope Stn 14. At this station moderate amounts of fucoxanthin (+fucoxanthin-like) and chlorophyll derivatives were found in the sediment and only very low concentrations of fresh chl $a$ and fucoxanthin in the bottom water. 
Table 6. Principal phytopigment concentrations at the stations, in (a) ng $\mathrm{l}^{-1}$ for bottom water, (b) ng $\mathrm{g}^{-1}$ dry sediment for the 0 to $1 \mathrm{~cm}$ sediment layer. 'Fresh' phytopigments are marked with an asterisk. -: concentrations below detection level

\begin{tabular}{|c|c|c|c|c|c|c|c|c|}
\hline \multirow{2}{*}{ Pigment } & \multicolumn{2}{|c|}{ Deep stations } & \multicolumn{2}{|c|}{ Slope stations } & \multicolumn{4}{|c|}{ Shelf stations } \\
\hline & 3 & 19 & 20 & 14 & 12 & 23 & 29 & 30 \\
\hline \multicolumn{9}{|l|}{ (a) Bottom water } \\
\hline Chlorophyll $c_{3}{ }^{*}$ & - & - & - & - & - & - & 7 & 9 \\
\hline Chlorophyll $c_{1}{ }^{*}$ & - & - & - & - & - & - & - & 2 \\
\hline Chlorophyld $c_{2}$ & - & - & - & - & - & - & 2 & 15 \\
\hline Fucoxanthin-like & - & - & - & - & - & 4 & 12 & 17 \\
\hline Fucoxanthin ${ }^{*}$ & - & - & $<1$ & 1 & 10 & 13 & 29 & 11 \\
\hline$\beta$-Hexanoyloxyfucoxanthin " & - & - & - & - & 1 & 7 & 15 & 37 \\
\hline Alloxanthin & - & - & - & - & - & - & 2 & 5 \\
\hline Zeaxanthin & - & - & - & - & 2 & 3 & 5 & 14 \\
\hline Chlorophyll $b^{\bullet}$ & - & - & - & - & - & 12 & 17 & 41 \\
\hline Chlorophyll $a^{*}$ & $<1$ & 2 & $<1$ & 2 & 33 & 50 & 110 & 183 \\
\hline$\beta$-Carotene & - & - & - & - & - & 3 & 3 & 5 \\
\hline \multicolumn{9}{|l|}{ (b) 0-1 cm sediment } \\
\hline Fucoxanthin ${ }^{*}$ & - & - & - & 17 & 75 & 30 & 188 & 127 \\
\hline Fucoxanthin-like & - & - & - & 14 & 10 & 18 & 17 & 13 \\
\hline$\sum$ Phaeophorbides & - & - & - & 48 & 5 & 35 & 99 & 231 \\
\hline Alloxanthin & - & - & - & - & 14 & 24 & 44 & 70 \\
\hline Zeaxanthin ${ }^{\circ}$ & - & - & - & - & 15 & 4 & 31 & 153 \\
\hline Chlorophyll $b^{\circ}$ & - & - & - & - & - & 19 & - & 44 \\
\hline Chlorophyll $a^{\circ}$ & - & - & - & 8 & 29 & 55 & 107 & 230 \\
\hline Chl a derivative & - & - & - & 31 & - & - & - & - \\
\hline$\beta$-Carotene ${ }^{*}$ & - & - & - & - & 7 & 26 & 14 & 234 \\
\hline
\end{tabular}

Analysis of samples from the surface water (not shown in Table 6) showed the highest concentrations of chl a to be present over the slope Stns $14 \& 20$, and over the inner shelf Stn 23. Relatively low concentrations were found over the Ebro stations. Comparing bottom and surface water pigment compositions confirms the CTD results indicating that the water mass was stratified in the Gulf of Lions and completely mixed near the Ebro.

\section{DISCUSSION}

In order to quantify the export of organic matter from the shelf to deeper regions of the Gulf of Lions, information concerning a range of processes, including annual primary production, vertical particle fluxes from the water column, sedimentation rates and total metabolism of the benthic biota, is required. An example of such an extensive study is the SEEP project, carried out in the Mid-Atlantic Bight (Walsh 1988). Some of these processes have been the subject of earlier studies in the NW Mediterranean. Zuo et al. (1992) found a concomitant decrease in sediment accumulation and mixing rates going from the mouth of the Rhône across the shelf and slope to the deep basin. According to Zuo et al. (1992), 50\% of the material supplied by the Rhone is deposited near the river mouth and $10 \%$ or less is exported from the shelf to the upper slope.
If shelf export is restricted to and directed by canyons (Aloïsi et al. 1982, Monaco et al. 1987), then the activity of the biota on the slope and in the deep basin outside the influence of these canyons should merely reflect vertical particle fluxes. One such vertical flux event has been measured by Peinert et al. (1991) in the deep basin south of Toulon. They recorded a maximum particle flux during the spring phytoplankton bloom of ca $20 \mathrm{mg} \mathrm{C} \mathrm{m} \mathrm{m}^{-2} \mathrm{~d}^{-1}$ in a moored sediment trap at $2000 \mathrm{~m}$ depth in combination with a sinking velocity of $>140 \mathrm{~m} \mathrm{~d}^{-1}$. Two months later (August) this flux had decreased to $<5 \mathrm{mg} \mathrm{C} \mathrm{m}^{-2} \mathrm{~d}^{-1}$ The values from Peinert's study agree reasonably well with our present estimates for the benthic carbon demand at this depth ( 9 to $14 \mathrm{mg} \mathrm{C} \mathrm{m}^{-2} \mathrm{~d}^{-1}$ ), suggesting that the vertical carbon flux might be sufficient to sustain the SOD rates for the deep stations.

During the present November cruise, the shelf stations yielded the highest incubation and diffusive fluxes of oxygen, as well as the highest irrigation fluxes, indicating a relatively high sediment content of metabolizable carbon in combination with intensified infaunal irrigation. The higher respiration rate at the nearshore Stn 19 compared to the offshore Stn 3, in combination with the lack of an irrigation flux at both stations (Table 2), suggests a relatively elevated detrital pool near the foot of the slope. Our data on $\mathrm{C} / \mathrm{N}$ ratios and sediment pigment, however, failed to show a clear difference between the 2 deep stations. 
Although both incubation and diffusive silicate fluxes decreased with increasing water depth, the differences between them were not the same as for oxygen (Tables 2 \& 3, Figs, 4 \& 6). For silicate, for instance, the differences between incubation and diffusive fluxes at the shelf stations and Stn 14 seem to be greater than for oxygen fluxes at these stations. This might be primarily the result of underestimation of the diffusive Si fluxes, due to lack of vertical resolution in the pore-water Si profiles $(0.5 \mathrm{~cm})$ compared to that in the oxygen profiles $(0.5 \mathrm{~mm})$. Secondly, the different kinetic behaviour of oxygen and silicate in the sediment (zero-order consumption for oxygen vs first-order dissolution of biogenic silicate could be responsible for different effects of bioirrigation on the fluxes of these compounds (Aller 1980, Berner 1980, Rutgers van der Loeff et al. 1984, Helder \& Andersen 1987).

Earlier flux measurements in this area have been carried out by Blackburn \& Lomstein (1989), Helder (1989b) and Blackburn (1991). Both incubation and diffusive fluxes of oxygen and silicate were determined in these studies. Generally, their flux rates were of the same order as those in the present study, with some exceptions, such as the higher oxygen incubation fluxes of December 1988 reported by Blackburn \& Lomstein (1989). Diffusive silicate fluxes measured in December 1988 by Helder (1989b) were considerably lower than the present ones. With respect to the seasonal variation of SOD in the area, it seems that the rates of November-December are maintained throughout the second half of the year, without large summer/ winter differences. This pattern probably also holds for the early spring, as can be deduced from the data reported by Blackburn (1991) from April-May 1991. Because of the good correlation between SOD and macrofaunal density (Tables $2 \& 4$ ), it is reasonable to assume that the observed pattern also reflects the annual pattern in benthic food input and activity. There are, however, no respiration data to support this supposition for the period of the spring phytoplankton bloom, which is an important source of benthic carbon (Peinert et al. 1991).

Our present SOD values for the 3 depth zones fit in the global ranges given in 2 compilations of various SOD studies by Jørgensen (1983) and Canfield (1989). The SOD data for deep-sea sediments given in these compilations are based either on in situ incubations or on pore-water profiles. According to Smith (1978), shipboard incubations of deep-sea sediment result in overestimates due to pressure effects on the biota. Also in the case of shipboard-measured pore-water profiles, a flux calculation can be overestimated due to the decompression of deep-sea sediment cores, leading to upward displacement of pore waters and artificially steepened interfacial gradients (Jahnke et al. 1989, Helder unpubl. results). Although we realize that, especially for the deeper stations, this makes a comparison between our shipboard-measured fluxes and the earlier reported in situ SOD values disputable, the fact that these values are of the same order, even if our data are really overestimated, suggests there is little evidence for substantial downslope transport of organic matter at our stations.

Supplementary evidence for the lack of a substantial export can be derived from a comparison between primary production and SOD assuming loss rates given by Suess (1980), i.e. $1 \%$ of the primary production for the deep sea and less than 10\% for the slope. In the oligotrophic surface waters overlying the slope, primary production varies between 50 and $100 \mathrm{~g} \mathrm{C} \mathrm{m}^{-2}$ $\mathrm{yr}^{-1}\left(150 \mathrm{~g} \mathrm{C} \mathrm{m}^{-2} \mathrm{yr}^{-1}\right.$ at the adjacent front). Primary production over the deep area is estimated to range between 80 and $150 \mathrm{~g} \mathrm{C} \mathrm{m}^{-2} \mathrm{yr}^{-1}$ (M. Minas \& H. J. Minas pers. comm.). These values would correspond to an input of 5 to $10 \mathrm{~g} \mathrm{C} \mathrm{m}^{-2} \mathrm{yr}^{-1}$ for the slope and $2 \mathrm{~g} \mathrm{C}$ $\mathrm{m}^{-2} \mathrm{yr}^{-1}$ or less for the deep area. When we convert our present SOD estimates into carbon, assuming no seasonal variation, the resulting carbon demands for the 2 areas are quite close to the predicted carbon inputs, i.e. 3 to $5 \mathrm{~g} \mathrm{C} \mathrm{m}^{-2} \mathrm{yr}^{-1}$ for the deep stations and 8 to $16 \mathrm{~g} \mathrm{C}$ $\mathrm{m}^{-2} \mathrm{yr}^{-1}$ for the slope stations, given the imprecision of the calculations.

The benthic activity pattern we found in November corresponded to some extent with the distribution of phytodetritus in the sediment, viz. relatively high amounts of fresh material on the shelf sediments and lower, more degraded material at the shallowest slope Stn 14. We were unable to detect phytopigments in surface sediments of deeper stations, probably because of the small amounts of sediment that we used for the analysis. But even with larger amounts the difference between Stn 14 and the deeper stations would have remained and would still contrast with the uniformity of the bottom water over the slope and deep stations. We therefore assume that Stn 14 received a pulse of phytodetritus prior to our visit, probably from a source other than the present layer of bottom water, as can be inferred from the high proportion of fucoxanthin-like pigments. Shelf bottom water or resuspended shelf sediments, which both could have been the source for this phytodetritus, were obviously not present at the time of the expedition. The bottom water over the slope and shelf differed clearly in pigment content and composition, indicating no exchange between shelf and slope. Moreover, the absence of phaeophorbides in any of the bottom water samples, although abundantly present in the shelf deposits, indicates that little or no resuspended phytodetritus was present on the shelf. 
Acknowledgements. We thank Captain de Jong, officers and crew of the RV 'Tyro' for their cooperation and providing a safe journey. Harry de Porto and his technicians are thanked for their skilled sampling of water and sediments and Karel Bakker and Annet van Koutrik for analyzing nutrients. Further we are indebted to Lutz Lohse for making the on deck oxygen profiles, Albert Kok for counting the meiofauna and for valuable assistance in preparing figures and Rikus Kloosterhuis for help with the $\mathrm{C} / \mathrm{N}$ analysis. Financial support came from the EC-MAST programme, contract No. EV4V0111-F(CD).

\section{LITERATURE CITED}

Abele-Oeschger, D. (1991). Potential of some carotenoids in two recent sediments of Kiel Bight as biogenic indicators of phytodetritus. Mar. Ecol. Prog. Ser. 70: 83-92

Aller, C. (1980). Quantifying solute distributions in the bioturbated zone of marine sediments by defining an average microenvironment. Geochim. Cosmochim. Acta 44: 1955-1966

Aller, R. C., Aller, Y. Y. (1992). Meiofauna and solute transport in marine muds. Limnol. Oceanogr. 37(5): 1018-1033

Aloisi, J. C., Cambon, J. P., Carbone, J., Cauwet, G., Millot, C., Monaco, A., Pauc, H. (1982). Origine et rôle du nepheloïde profond dans le transfert des particules en milieu marin. Application au Golfe du Lion. Oceanol. Acta 5(4): $481-491$

Archer, D., Devol, A. (1992). Benthic oxygen fluxes on the Washington shelf and slope: a comparison of in situ microelectrode and chamber flux measurements. Limnol. Oceanogr. 37(3): 614-629

Berner, R. A. (1980). Early diagenesis: a theoretical approach. Princeton University Press, Princeton

Bidigare, R. R. (1991). Analysis of algal chlorophylls and carotenoids. In: Hurd, D. C., Spencer, D. N. (eds.) Marine particles: analysis and characterisation. Geophysical Chromograph 63, American Geophysical Union, Washington, DC, p. 119-123

Blackburn, T. H. (1991). Mineralization in northwestern Mediterranean sediments: Cybele cruise. In: Martin, J.-M., Barth, H. (eds.) EROS 2000 (European River Ocean System) Project Workshop Blanes. Water Pollution Research Report, CEC Directorate-General for Science, Research and Development, Brussels, 28: 469-479

Blackburn, T. H., Lomstein, B. A. (1989). Carbon and nitrogen mineralization in Gulf of Lions sediments. In: Martin, J.-M., Barth, H. (eds.) EROS 2000 (European River Ocean System) Project Workshop Paris 7-9 March 1989. Water Pollution Research Report, CEC Directorate-General for Science, Research and Development, Brussels, 13: 102-111

Bloom, S. A. (1981). Similarity indices in community studies: potential pitfalls. Mar. Ecol. Prog. Ser. 5: 125-128

Broecker, W. S., Peng, T H. (1974). Gas exchange rate between sea and air. Tellus 26: 21- 35

Canfield, D. E. (1989). Sulfate reduction and oxic respiration in marine sediments: implications for organic carbon preservation in euxinic sediments. Deep Sea Res. 36: $121-138$

Cruzado, A., Velasquez, Z. R. (1989). Nutrient distribution in the Gulf of Lions, winter 1989. In: Martin, J.-M., Barth, H. (eds.) EROS 2000 (European River Ocean System) Project Workshop Paris 7-9 March 1989. Water Pollution Research Report, CEC Directorate-General for Science, Research and Development, Brussels, 13: 67-78
Emerson, S. K., Fischer, K., Reimers, C., Heggie, D. (1985) Organic carbon dynamics and preservation in deep-sea sediments. Deep Sea Res. 32: 1-21

Got, H., Aloïsi, J.-C., Monaco, A. (1985). Sedimentary process in Mediterranean deltas and shelves. In: Keuly, D. J., Wesel, F. C. (eds.) Geological evaluations of the Mediterranean basins, Vol. 7. Springer-Verlag, Berlin, p. 355-376

Hall, P. O. J., Anderson, L. G., Rutgers van der Loeff, M. M., Sundby, B., Westerlund, S. F. G. (1989). Oxygen uptake kinetics in the benthic boundary layer. Limnol. Oceanogr. 34: $734-746$

Hargrave, B. T. (1973). Coupling carbon flow through some pelagic and benthic communities. J. Fish. Res. Bd Can. 30 $1317-1326$

Helder, W. (1989a). Early diagenesis and sediment-water ex change in the Savu basin (eastern Indonesia). Neth. J. Sea Res. 24(4): 555-572

Helder, W. (1989b). Early diagenesis and sediment-water exchange in the Golfe du Lion. In: Martin, J.-M., Barth, H. (eds.) EROS 2000 (European River Ocean System) Project Workshop Paris 7-9 March 1989. Water Pollution Research Report, CEC Directorate-General for Science, Research and Development, Brussels, 13: 87-101

Helder, W., Andersen, F. $\varnothing .(1987)$. An experimental approach to quantify biologically mediated dissolved silicate transport at the sediment-water interface. Mar. Ecol. Prog. Ser. 39: 305-311

Jahnke, R. A., Emerson, S. R., Reimers, C. E., Schuffert, J., Ruttenberg, K., Archer, D. (1989). Benthic recycling of organic debris in the eastern tropical Atlantic Ocean. Geochim. Cosmochim. Acta 53: 2947-2960

Jergensen, B. B. (1983). Processes at the sediment-water interface. In: Bolin, B., Cook, R. B. (eds.) The major biochemical cycles and their interactions. SCOPE 21, John Wiley \& Sons, Chichester, p. 477-509

Kanneworff, E., Christensen, H. (1986). Benthic community respiration in relation to sedimentation of phytoplankton in the Oresund. Ophelia 26: 269-284

Kraay, G. W., Zapata, M., Veldhuis, M. J. W. (1992). Separation of chlorophylls $c_{1}, c_{2}$ and $c_{3}$ of marine phytoplankton by reverse-phased $\mathrm{C} 18$ high-performance liquid chromatography. J. Phycol. 28: 708-712

Li, Y., Gregory, S. (1974). Diffusion of ions in sea water and deep-sea sediments. Geochim. Cosmochim. Acta 38: 703-714

Millot, C. (1987). Cirulation in the Western Mediterranean Sea. Oceanol. Acta 10(2): 143-149

Minas, M., Minas, H. J. (1989). Primary production in the Gulf of Lions with considerations to the Rhône river input. In: Martin, J.-M., Barth, H. (eds.) EROS 2000 (European River Ocean System) Project Workshop Paris 7-9 March 1989. Water Pollution Research Report No. 13, CEC DirectorateGeneral for Science, Research and Development, Brussels, 13: 112-125

Monaco, A., Heussner, S., Courp, T., Buscail, R., Fowler, S. W., Millot, C., Nyffeler, F. (1987). Particle supply by nepheloid layers on the Northwestern Mediterranean margin. Mitt. geol. -paläont. Inst. Univ. Hamb. (SCOPE/UNEP Sdbd) 62: 109-125

Peinert, R. D., Fowler, S. W., La Rosa, J., Miquel, J.-C., Teyssie, J.-L. (1991). Vertical flux and microplankton assemblages in the Gulf of Lions during spring 1990. In: Martin, J.-M., Barth, H. (eds.) EROS 2000 (European River Ocean System) Project Workshop Blanes. Water Pollution Research Report, CEC Directorate-General for Science, Research and Development, Brussels, 28: 413-424

Rasmussen, H., Jørgensen, B. B. (1992). Microelectrode 
studies of seasonal oxygen uptake in a coastal sediment: the role of molecular diffusion. Mar. Ecol. Prog. Ser. 81: 289-303

Revsbech, N. P., Sørensen, J., Lomholt, J. P., Blackburn, T. H. (1980). Distribution of oxygen in marine sediments, measured with microelectrodes. Limnol. Oceanogr. 25(3): 403-411

Rumohr, H., Brey, T., Ankar, S. (1987). A compilation of biometric conversion factors for benthic invertebrates of the Baltic Sea. Baltic mar. Biol. Publ. 9: 1-56

Rutgers van der Loeff, M. M., Anderson, L. G., Hall, P. O. J., Iverfeldt, A., Jozefson, A. B., Sundby, B., Westerlund, S. F. G. (1984). The asphyxiation technique: an approach to distinguishing between molecular diffusion and biologically mediated transport at the sediment-water interface. Limnol. Oceanogr. 29(4): 675-686

Rutgers van der Loeff, M. M., Lavaleye, M. M. S. (1986). Sediments, fauna and the dispersal of radionuclides at the N. E. Atlantic dumpsite for low-level radioactive waste. Report of the Dutch DORA program. Netherlands Institute for Sea Research, Texel

Schaff, T., Levin, L., Blair, N., DeMaster, D., Pope, R., Boehme, S. (1992). Spatial heterogeneity of benthos on the Carolina continental Slope: large $(100 \mathrm{~km})$-scale variation. Mar. Ecol. Prog. Ser. 88: 143-160

Smith, K. L. Jr (1978). Benthic community respiration in the N. W. Atlantic Ocean: in situ measurements from 40 to 5200 m. Mar. Biol. 47: 337-347

Strickland, J. D., Parsons, T R. (1972). A practical handbook of seawater analysis, 2nd edn. J. Fish. Res. Bd Can. 167: $1-311$

This article was submitted to the editor
Suess, E. (1980). Particulate organic carbon flux in the oceans - surface productivity and oxygen utilization. Nature 288: 260-263

Thiel, H. (1966). Quantitative Untersuchungen über die Meiofauna des Tiefseebodens. Veröff. Inst. Meeresforsch. Bremerh. (Sdbd) 2: 131-148

Uhlig, G., Thiel, H., Gray, J. S. (1973). The quantitative separation of meiofauna. A comparison of methods. Helgoländer wiss. Meeresunters. 25: 173-195

Ullman, W. J., Aller, R. C. (1982). Diffusion coefficients in nearshore marine sediments. Limnol. Oceanogr. 27: $552-556$

van Duyl, F. C., Kop, A. J., Kok, A., Sandee, A. J. J. (1992). The impact of organic matter and macrozoobenthos on bacterial and oxygen variables in marine sediment boxcosms. Neth. J. Sea Res. 29(4): 343-355

Verardo, D. J., Froelich, P. N., McIntyre, A. (1990). Determination of organic carbon and nitrogen in sediments using the Carlo Erba NA--1500 analyzer. Deep Sea Res. 37: $157-165$

WaIsh, J. J. (1988). Shelf edge exchange processes of the MidAtlantic Bight. Cont. Shelf Res. 8(5-7): 433-947

Wollast, R., Garrels, R. M. (1971). Diffusion coefficients of silica in seawater. Nature 229: $94-100$

Zuo, Z., Eisma, D., Gieles, R. (1992). Effect of particle transport and mixing on ${ }^{210} \mathrm{~Pb}$ distribution in the Northwest Mediterranean Sea. In: Martin, J.-M., Barth, H. (eds.) EROS 2000 (European River Ocean System) Project Workshop Blanes. Water Pollution Research Report, CEC Directorate-General for Science, Research and Development, Brussels, 28: 1425-1436

Manuscript first received: June 25, 1993

Revised version accepted: October 1, 1993 